\title{
Introduction: Masculinity and Politik
}

by Christopher Fletcher

IRHiS (UMR 8529)

CNRS / Université de Lille, F-59000 Lille, France

\begin{abstract}
What do we mean by politics [Politik]? The concept is extremely broad and includes every kind of independent leadership activity. We can speak of the foreign exchange policies of the banks, the interest rate policy of the Reichsbank, the politics of a trade union in a strike; we can speak of educational policy in a town or village community, the policies of the board of management of an association, and even of the political manoeuvrings [Politik] of a shrewd wife seeking to influence her husband. Needless to say, this concept is far too broad for us to consider this evening. Today we shall consider only the leadership, or the exercise of influence on the leadership, of a political organization, or in other words a state. ${ }^{1}$
\end{abstract}

When Max Weber set out to consider Politik in the broadest possible terms at the start of a lecture delivered in 1919, it went without saying that almost every area of 'political' life would be monopolized by men. Despite the recent expansion of the franchise in post-revolutionary Germany to permit women to vote and to stand for election, both the 'politics' and the 'policy' of private and national banks and of management boards remained the monopoly of adult males, and trade unions and public office were overwhelmingly dominated by men. ${ }^{2}$ Only in more local and more informal arenas, ones closer literally to home, such as educational policy, religious life and the domestic sphere itself, did Politik cease to be almost exclusively masculine.

For two millennia and more before Weber spoke, formal political authority in Europe was normally and ideally in the hands of adult males. Normally because this was most often the case and because this formed a norm whose regularity served as proof of its naturalness. Ideally because male authority was felt to be the ideal and female authority the aberration. This is not to say that women at all social levels did not exercise informal authority and especially 'power through the family', much like Weber's 'shrewd wife'. ${ }^{3}$ Nor is it to set aside the numerous occasions where women have exercised formal political authority: in medieval and early modern Europe, for example, in which women frequently wielded authority as independently influential noblewomen, as queens regent or as queens regnant. ${ }^{4}$ All the same, female power, despite its ubiquity, was perceived until very recently as a kind of a recurrent contradiction, a paradox which refused to go away. ${ }^{5}$ In particular, the norm and the ideal that formal political power would be masculine created vulnerabilities for powerful women which adult male rulers did not experience.

This state of affairs was arguably intensified by the gradual process of formalisation which Weber sketched out influentially in the meat of his lecture. As Weber tells this story, the 'means of administration' and particularly the monopoly of legitimate violence which were now in the hands of the state had once been distributed amongst many different actors and groups, from powerful nobles to city states. ${ }^{6}$ These 'means' had first been gradually absorbed by kings and princes, in particular by assuming the role of the agents of public authority, the authority of the res publica or common good once claimed exclusively by Roman emperors. According to Weber, monarchs then

Institutional deposit of pre-copy-edited version. Please consult and cite: Christopher Fletcher, 'Introduction: Masculinity and Politik' in Christopher Fletcher, Sean Brady, Rachel E. Moss and Lucy Riall, eds., The Palgrave Handbook of Masculinity and Political Culture in Europe (London: Palgrave Macmillan, 2018), pp. 1-16. DOI: 10.1057/978-1-13758538-7 
in turn found their power gradually sapped by the administrators they needed to govern such an extensive and elaborate apparatus. These administrators were alienated from the means of administration at their disposal, in the sense that, like the functionaries of a large company, they managed these resources but did not own them. The 'state' in its full form thus came into being: an ensemble of administrative, fiscal and judicial apparatus which different groups might seek to control. This was 'politics' in Weber's narrow sense: the competition for control of formal institutions possessed of a monopoly of legitimate violence. ${ }^{7}$

These developments also had significant gendered consequences which Weber did not identify. A recurring theme in European politics between the Roman Empire and the contemporary world is the move by different political actors to mobilize the res publica, the common good or the public weal. ${ }^{8}$ Kings and princes as much as city administrations invoked their public authority, in the sense of their authority deriving from their role as the protectors of the welfare of the people, to justify their rights to administer justice, to legislate, to raise taxation and to wage war. This did not mean that all rights of justice, legislation, taxation and violence were legitimated in this way, far from it, but it did introduce a form of political authority which was significantly different from power justified by private right, hereditary status or custom. The more public authority was perceived as public, in the sense of serving the common good of the people, the less acceptable it was that informal influence or even the rights of particular individuals or groups should play a role in policy or politics. One central aspect of these developments which historians have not explored is that government in the name of the common weal was more overwhelmingly masculine than any form of rule that had come before it. ' Women's informal influence and even formal political authority continued, of course, but because the political authority of the 'state' was based not on individual status, custom or collective privileges but on the absolute good of the res publica, these forms of female power, even whilst they continued, were now perceived as an even more uncomfortable aberration. For centuries, this was not perceived as a difficulty: the only problem was that women did still ostensibly wield power, and ways had to be found to justify these states of exception. Only in the eighteenth and nineteenth centuries did the exclusion of women from formal politics begin to seem unacceptable to some. The slow admission of women into electoral democracy was perceived as the cure for this malady, yet it is clear that in the vast majority of modern Western democracies it has still not proved effective. 'Politics' conceived of as the politics of the state may no longer be ideally or even exclusively the preserve of men, but it remains an overwhelmingly masculine domain. ${ }^{10}$

It is in this context that the present 'handbook' seeks to make a contribution. The chapters in this book explore from multiple angles and over a long period the mechanisms by which the maleness of formal political power has been established and maintained across successive generations. They examine how these mechanisms have marked European political culture over the long term, and still marks it today.

Institutional deposit of pre-copy-edited version. Please consult and cite: Christopher Fletcher, Introduction: Masculinity and Politik' in Christopher Fletcher, Sean Brady, Rachel E. Moss and Lucy Riall, eds., The Palgrave Handbook of Masculinity and Political Culture in Europe (London: Palgrave Macmillan, 2018), pp. 1-16. DOI: 10.1057/978-1-13758538-7 
It is clear that to pursue these issues we cannot, like Max Weber, begin by limiting ourselves to the kind of formal political institutions familiar from the European nation states of the past two or three centuries. If politics is the struggle to exercise leadership over 'a political organization, or in other words a state', then an analysis of masculinity and political culture could confine itself to the analysis of the influence of gendered ideas and values over the kind of politics which takes place in representative institutions or within the apparatus of the state. This is certainly one legitimate approach to the study of masculinity and political culture, and many contributions to the present volume take it as their central theme. ${ }^{11}$ Nonetheless such a line of analysis quickly becomes problematic if it is pursued exclusively. In pre-industrial contexts especially, where the means of coercion were less effective, where communications were not as developed, and where judicial and fiscal machinery required the cooperation of non-state agents to work, the study of politics cannot be limited to the study of the state. ${ }^{12}$ To understand the interaction between the maleness of power and the nature of politics over the longue durée, we need to begin with a broader definition of political culture than has so far been applied in studies of masculinity and politics in the relatively recent past.

Nor is the need for a broad conception of 'politics' limited to the study of the pre-modern past. It is clear that even when contemporary Europe is in question, a state-based approach to politics is not sufficient for an effective analysis of political authority and gender. Critics of modern liberal democracy on left and right, from Weber and Carl Schmidt ${ }^{13}$ to Pierre Bourdieu ${ }^{14}$ and Pierre Rosanvallon ${ }^{15}$ have noted the inadequacy of any vision of politics which restricts itself to the 'occasional' politics of the ballot box, to the institutions of electoral democracy or the activities of the modern state. ${ }^{16}$ It is thus all the more necessary to take a broad view of political culture which takes in not only the state-centred vision of politics put to the fore by Weber, but also all those areas of Politik, which he identified but chose not to discuss. After all, one aim of the earliest studies of gender history was to disrupt the division between public and private which placed men in the former sphere and women in the latter. ${ }^{17}$ It thus seems only natural to turn around Weber's casually sexist aside about the scheming wife in order to insist that gender relations in the household are indeed an important kind of politics, and that any global vision of the political culture of a given society must include them also. ${ }^{18}$

Gender historians and political historians have often had an uneasy relationship in recent decades. It remains the case both that gendered approaches to political history have had difficulty finding acceptance within that broader field, and that historians of gender have proved wary of straying into political history. Certainly, if one compared the aims and methods of gender historians and political historians before the 1970s, it would appear difficult to reconcile them. Yet it is true that even as gender history was emerging, so political history was gradually undergoing a transformation which could be traced back to initiatives begun some decades before. ${ }^{19}$ Prosopographical methods brought the study of politics closer to social history than it had ever been, consciously distancing modern research from the excessively institutional and legal perspective of earlier writers. Already by the 1980s, political history and gender history were not so distant in their methods. The growing 
interest in cultural history touched both sub-disciplines at the same times and in a similar fashion. The concept of 'political culture' in particular has made it possible to push back the boundaries of political history to cover not only the political thought found in learned and not-so learned treatises, but also the unspoken assumptions and expectations of different social groups about how government ought to work. ${ }^{20}$ The time thus seems ripe to bring gender history and political history together, taking both politics and gender equally seriously.

Reasons of good practice and the state of current research thus encourage a broad definition of politics and a long range of study. It is for these reasons that a handbook dedicated to masculinity and political culture includes not only studies of masculinity in representative institutions and the gendered nature of the expansion of the electoral franchise, for example, but also studies of the action of class and authority in the life of a judge and 'closeted' homosexual in late nineteenth- and early twentieth-century Strasbourg, or of the significance of gendered notions of honour and right action for the elites of fifteenth-century Spanish towns. ${ }^{21}$ In seeking to understand how the normal and ideal maleness of power has affected European political culture over the very long term, the contributors to this volume have ranged widely beyond the state, all whilst keeping to Weber's central concern with 'leadership' and with 'influence'. One result is that the present volume is avowedly a 'handbook' and not a 'textbook'. It aims to offer a wide-ranging selection of specialist studies, designed to be accessible to the non-specialist, but privileging access to the best recent research.

What might perhaps surprise specialist readers more than this broad conception of political culture is the use of the term 'masculinity'. 'Masculinity' is one of those dangerous words for the researcher which combines both a technical usage and broad, often unacknowledged modern associations. ${ }^{22}$ Both in the popular psychology of the modern day and in much of the specialist literature, it is common to consider that adult males have a need to 'prove their masculinity' by aggressive action, and above all by sexual activity. ${ }^{23}$ The contributors to this volume, although many of them do consider sexuality, have not found this to be a helpful model for understanding the cases they consider. Instead, they are closer in their methodology to the sociologist Raewyn Connell, whilst adapting and refining her work for application to societies and cultures which are in some cases very distant from the contemporary, Western, Anglophone case studies which she considers.

Connell has been widely influential, perhaps especially amongst historians, because of the usefulness of the pluralising conception of 'masculinities' first developed in her works. Thinking of 'masculinities' instead of 'masculinity' serves to catch the way in which the fact of being a man will not be lived in the same way by a factory worker, for example, than by an office clerk, all whilst accepting certain commonalties of male bodily experience. ${ }^{24}$ For historical purposes, however, Connell's analysis requires some adaptation, not least because her use of the concept of 'masculinities' brings together several phenomena which are not analytically identical. 
These phenomena can usefully be distinguished as different understandings of what 'a masculinity' is. First, 'a masculinity' might be said to refer to a set of norms, values or forms of behaviour which are emphatically linked to acting 'manly' or 'like a man'. Such a 'masculinity' asserts its compulsory and ideal nature by seeking to link a set of social norms or behaviours to deep-running cultural and linguistic assumptions. When somebody asserts that such-and-such an action is 'manly' they are not only making a judgement in accordance with shared social norms, they are also drawing on a set of accepted uses of the word 'manly' in the language they use and the culture they share with their interlocutors. In Europe, many of these accepted uses stretch back into ancient Roman language and culture, ${ }^{25}$ and it is only in relatively recent times that sexual activity has come to be seen as the defining quality of 'masculinity'. In the Latin language, to act 'viriliter' is to be strong and vigorous, and more specifically to stand one's ground and not retreat in a combat situation. ${ }^{26}$ These values might be invoked in a real battle, or metaphorically in a mental attitude which shows steadfastness or constancy. The same values lie behind the multiple referents of the Latin 'virtus', which refers not only to what we call virtue, but also to steadfastness which is both physical and psychological, all with a clear reference to the fact of being a 'vir' (a 'man'). ${ }^{27}$ The use in European vernaculars of words such as 'manly', 'manhood' and equivalent words including 'virtue' has long been heavily influenced by this common cultural heritage. Certainly, the range of potential applications of such concepts is very large. They might be stretched, for example, to cover the qualities of moral virtue, ${ }^{28}$ or even credit worthiness. ${ }^{29}$ Nonetheless, these values are not infinitely malleable. It would be comic, even ungrammatical, to clean one's teeth like a man, but to fight or to suffer adversity like a man seems linguistically uncontroversial. Just so, the deep running associations attached to manhood in European culture permit certain forms of behaviour to be more easily denoted as fitting for adult males than others.

Second, and as a variant of the first approach, a 'masculinity' might also be a set of characteristics or behaviours routinely associated with males in a positive or negative fashion, although without this necessarily being linked to all men. Fatherhood is thus 'a masculinity' without it being experienced by all men. The sexual excess and other negative characteristics held to characterise young men in medieval culture can also be considered to be a 'masculinity'. ${ }^{30}$ Slightly paradoxically, from this point of view even 'effeminacy' is a masculinity, since it is a set of characteristics which can only meaningfully be applied to a man.

Third, 'a masculinity' might also denote a set of norms, ideals or practices which an historian or sociologist can identify as being either exclusively or usually applicable to adult males, even though the social actors in question are unaware of this and might even deny it. Practices like blood brotherhood in medieval Iceland concern only males, but this is nowhere explicitly stated. ${ }^{31}$ The individuals who assumed the role of the grey-suited technocrat or 'professor' in post-war Italian politics were all men, and yet their political self-presentation eschewed overt identification between their political persona and their masculinity. ${ }^{32}$ Yet from an analytical point of view the figure of the chess-playing professor is just as much a masculinity as, for example, the emphatically masculine

Institutional deposit of pre-copy-edited version. Please consult and cite: Christopher Fletcher, Introduction: Masculinity and Politik' in Christopher Fletcher, Sean Brady, Rachel E. Moss and Lucy Riall, eds., The Palgrave Handbook of Masculinity and Political Culture in Europe (London: Palgrave Macmillan, 2018), pp. 1-16. DOI: 10.1057/978-1-13758538-7 
military self-presentation adopted by Nazi politicians in the early $1930 \mathrm{~s}^{33}$ Indeed, it is a characteristic of many masculinities to deny that this is what they are, perhaps especially in politics.

Finally, 'a masculinity' might be a set of ideals, behaviours or practices which is implicitly associated with adult maleness in a particular group or period without this always being explicitly linked to manhood, although such a link was recognised in certain circumstances. In some contexts, it is the unspoken nature of these norms which might enable, for example, a patrician member of the Victorian House of Commons to identify expressions of emotion on the part of a working class MP as unmanly, whereas the latter believed himself to be demonstrating manly authenticity. ${ }^{34}$ In other contexts, such norms could be enunciated explicitly. In early modern England, for example, anxieties generated by differing norms of masculinity in different social groups created a market for manuals of correct comportment which enable outsider males to 'pass'. ${ }^{35}$ Didactic or moralistic texts might also seek to rectify masculine comportments which they took to be lax or corrupted, although in this case we have to be careful to assess just how widely accepted their strictures might be. ${ }^{36}$ This final kind of 'masculinity' thus lies somewhere between the first emphatic variety of masculinity and our third category of masculine norms or practices which we can identify as characteristically male without this being acknowledged by contemporaries. Instead, this final variety of 'masculinity' denotes a 'habitus' which is known to be characteristic of men in a given society or social group, although this is not always made explicit. ${ }^{37}$

The contributions to this volume thus explore masculinity taken as a broad field of study whilst permitting the authors to treat phenomena which take in any or all of these different approaches to 'a masculinity' as their subject matter allows. What brings them together is less a single theoretical viewpoint and more a common concern with the interaction between competing masculinities and changing forms of political culture. ${ }^{38}$ It is this ecumenical approach which has made it possible to assemble in one volume studies of masculinity and political culture in contexts stretching from ancient Rome to the contemporary West. Read as a whole they make it possible to perceive broad developments without the implicit teleology which has marked recent attempts to trace the history of particular cultural phenomena such as 'virilité' from antiquity to the present day, ${ }^{39}$ or the tendency to excessive schematization which has dogged, for example, attempts to periodize the history of masculinity in the British Isles. ${ }^{40}$ Instead what emerges is a slowly evolving palette of concepts and practices linked to ideal or deviant manhood which have played different roles in a broad variety of European political cultures. Sometimes appeals to emphatic or explicit masculinities have proved crucial in policing the boundaries of acceptable political activity and in particular its normal and ideal association with adult males. At others, the non-explicit nature of gendered practices has allowed these same boundaries to shift as pragmatic considerations dictated, admitting women and even eunuchs into the circle of masculine power.

The essays contained in this handbook each consider how, in different periods, gendered concepts and gendered practices have impinged on the exercise of political authority and influence. The volume opens with two contributions which consider the complex relationship between ideals of

Institutional deposit of pre-copy-edited version. Please consult and cite: Christopher Fletcher, Introduction: Masculinity and Politik' in Christopher Fletcher, Sean Brady, Rachel E. Moss and Lucy Riall, eds., The Palgrave Handbook of Masculinity and Political Culture in Europe (London: Palgrave Macmillan, 2018), pp. 1-16. DOI: 10.1057/978-1-13758538-7 
male patrician comportment and the broader culture of masculinity in the Roman Empire before and after Christianisation. For Cyril Dumas, the sexualised symbolism and phallic imagery which were ubiquitous in pagan society should not be seen as erotic in purpose, but rather as the flipside of a culture in which patrician men's claims to authority were conditional on the control of their bodies and on the subordination of sexual activity to reproduction. Mathew Kuefler continues this story into the later Roman Empire and past its fall in the West. Roman political and masculine values which had been revitalised and redirected by Christianity now found themselves under renewed pressure from the more overtly military masculine ideals of barbarian invaders and increasingly by formerly barbarian members of the Roman army. This revived tensions between the need to demonstrate status by conspicuous display and the need to show a hard, simple, manly exterior. Both Dumas and Kuefler consider the often difficult interaction between masculine ideals and political norms in a society which closely linked the virtues of public life to the characteristics of an ideal adult male.

The overt linkage between masculinity and political power was not always so straightforward, however. In exceptional circumstances, in late antiquity or in the Middle Ages, gendered norms could be overcome to permit individuals to assume forms of authority from which they would normally be excluded. In different contexts, social practices essential for the exercise of political authority were not perceived as especially masculine even though they were heavily associated with being a man. Georges Sidéris considers how, in the late fourth century, the eunuch Eutropius was able, as a result of political circumstances, to overcome the normal exclusion of eunuchs from military command to lead a successful campaign in 396-7 and to attain the consulship in 399. Only retrospectively, after Eutropius's disgrace, did it become legally impossible for a eunuch to attain the summits of political power. Laurence Leleu, meanwhile, considers how women who assumed positions of power in the tenth-century Ottonian empire, such as the Empress Theophano, could be praised without difficulty and without a sense of inversion, ascribing them the ideal virile qualities of male rulers. Accusations of soft effeminacy could be used just as effectively against male political actors. Finally, Pragya Vohra examines the nature of Icelandic kinship groupings which, in a society without any formal governmental institutions, were one of the primary means by which political actors could achieve their ends. In contrast to the late Roman or Ottonian empire, structures such as blood brotherhood, while overwhelmingly concerning relationships between men, were not perceived as such. In Iceland, the maleness of political power did not play the same kind of ideological role which it did in early medieval continental Europe.

In the political cultures of central and later medieval Europe norms of masculinity continued to provide a powerful group of themes with which political actors, whether they be churchmen, townsmen or nobles, could positively present their own actions or undermine the actions of their opponents. Matthew Mesley explores the ambiguous position of the bishops of twelfth and thirteenth century Germany with regards to norms of political authority. In early work on medieval masculinity, churchmen tended to be treated as fundamentally different from laymen, on account of their theoretical exclusion from sexual activity. Only recently has attention been drawn to how

Institutional deposit of pre-copy-edited version. Please consult and cite: Christopher Fletcher, 'Introduction: Masculinity and Politik' in Christopher Fletcher, Sean Brady, Rachel E. Moss and Lucy Riall, eds., The Palgrave Handbook of Masculinity and Political Culture in Europe (London: Palgrave Macmillan, 2018), pp. 1-16. DOI: 10.1057/978-1-13758538-7 
clerics had much in common with their social equals amongst the laity. This article extends this investigation to elite churchmen, focussing on the theme of masculine fidelity in the career Adolf of Altena, bishop of Cologne. Hippólita Rafael Oliva Herrer examines how, in the Iberian peninsula from the later thirteenth until the fifteenth century, ideals of masculinity which had initially been set out most clearly in clerically authored guides for rule known as 'mirrors for princes' increasingly came to play a role in the definition of good rule, even at the level of the ideal behaviour of the mayor of a town. Urban leaders could gain legitimacy, notably in comparison to noble leaders, by demonstrating exemplary self-control and the upright and honourable behaviour of an established householder. Finally, Hugo Dufour considers the contrasting ways in which the leaders of different factions in the political upheavals of the late fourteenth- and fifteenth- century France managed the relationship between their own masculinity and authority, or used gendered terms to attack their opponents. Burgundian propagandists made use of topoi of excessive, warlike masculinity or sexually sinful effeminacy to smear their opponents, leaving for posterity the image of the Louis, duke of Orléans as a luxurious dandy. The austere tomb monument he commissioned presents his manhood very differently, in contrast to the magnificent but traditional manliness projected by the tomb of his enemy, John the Fearless.

Early modern historians, and perhaps especially those working on the British Isles, have long included gender and more recently masculinity in their account of society. The contributions of Susan Doran and Ann Hughes build upon this work with two essays focused on specifically British examples which consider how different masculinities negotiated with one another in political culture in the sixteenth and seventeenth centuries. Susan Doran argues that although the reigns of Edward VI, Mary I, Elizabeth I and James I all put conventional ideas of masculine rule under pressure in different ways - first through the rule of a minor, then a queen regnant with an absentee husband, then an unmarried woman, and finally a man who often did not conform to gender norms of masculinity - the political culture of the day adapted to accommodate this variety, even if Charles I later felt the need to restore the image of monarchical masculinity. Ann Hughes, meanwhile, considers how the civil war both enhanced and placed under pressure existing conceptions of male rule. The war disrupted the perception of the king as father, but added new charge to the linkage between elite masculinity and public office, on the one hand, and the right to bear arms, on the other. She considers how both 'cavalier' and 'roundhead' models of political activism developed, sometimes in explicit contrast to the growing possibility for female agency which had emerged in the religious and political upheavals of the 1640s and 1650s. Both Doran and Hughes suggest the broad continuities in gendered ideology despite the political upheavals of this period. It seems less that social change led to a crisis of masculinity, and more that political and social upheaval made explicit and implicit norms of masculine authority all the more valuable in the attempt to establish political legitimacy.

Ideals of manhood in the eighteenth and nineteenth centuries in some ways had much in common with their pre-modern forebears. Vigour, honourable conduct and self-control continued to be associated with ideal manhood, whilst effeminate changeability, sexual excess and luxury were still

Institutional deposit of pre-copy-edited version. Please consult and cite: Christopher Fletcher, Introduction: Masculinity and Politik' in Christopher Fletcher, Sean Brady, Rachel E. Moss and Lucy Riall, eds., The Palgrave Handbook of Masculinity and Political Culture in Europe (London: Palgrave Macmillan, 2018), pp. 1-16. DOI: 10.1057/978-1-13758538-7 
portrayed as the roots of political vice. Nonetheless, behind these deep continuities, there were also profound changes, and, on occasion, explicit attempts to question the established gender order. On the one hand, the shocks of the late eighteenth and early nineteenth centuries, from political revolutions to industrialisation, could provoke a critique of traditional gender values; on the other, it could equally well lead to their reassertion.

Matthew McCormack and Henry French consider the interplay of these transformations in Britain eighteenth and nineteenth-century Britain, exploring how large scale political and cultural shocks had an impact on the personal and political lives of individual men. McCormack takes a synthetic perspective, considering how historians have begun to integrate masculinities into their analysis of the political culture, from political representation, to the history of the body, the emotions and material culture. Henry French focuses this account through a study of the career of one politician, William Windham (1750-1810). During his own lifetime and in the immediate aftermath of his death, Windham's reputation was high, and he was celebrated for his commitment to his own vision of the right course of political action, even when this led him to disconcerting political choices and changes of position. With the publication of his personal diary in the mid-nineteenth century, this reputation was drawn into question, with the revelation of his vigorous selfexamination, hypochondria, and doubts about his own abilities. French reconsiders 'weathercock Windham's' posthumous fortunes to portray a man who was, in part, a victim of the changing focus of nineteenth century ideals of masculinity, away from authenticity and towards self-control.

Acceptance and submission to ideals of masculine authority, leading to a recurring sense of failure and inadequacy, were not the only possibilities available in the late eighteenth and nineteenth centuries. In the wake of the political, social and economic transformations of these years, it was also newly possible to perceive the gender order for the ideological construction that it was. Opposition and subversion brought with them consequences which were sometimes political, sometimes social. Victoria Russell considers the development of the Romantic critique of norms of masculinity and femininity, which although at first highly politicised, found its longer term success in the quietist form of social and educational reform, insisting on the gender-neutral nature of the majority of human intellectual characteristics. Allison Goudie, meanwhile, considers the ambiguous reception of Antonio Canova's statue of Ferdinand IV of Naples, commissioned in 1800, widely interpreted as 'Ferdinand IV in the guise of Minerva'. As such, it encodes a critical stance towards the involvement of Ferdinand's wife, Maria Carolina, in government. Even traditional conceptions of masculinity could be used to question established authority in circumstances of profound political and social upheaval.

Sexuality, too, opened up the possibility of distance from and criticism of the established political order, even when this critique remained latent. Régis Schlagdenhauffen thus considers the personal diary of the Franco-German jurist Eugène Wilhelm (1885-1951). Wilhelm exercised the authority of a judge, condemning homosexuals amongst other deviants, all whilst continuing homosexual relationships, sometimes over several decades, with men who might be considered to be members

Institutional deposit of pre-copy-edited version. Please consult and cite: Christopher Fletcher, Introduction: Masculinity and Politik' in Christopher Fletcher, Sean Brady, Rachel E. Moss and Lucy Riall, eds., The Palgrave Handbook of Masculinity and Political Culture in Europe (London: Palgrave Macmillan, 2018), pp. 1-16. DOI: 10.1057/978-1-13758538-7 
of the underclass. His diary is a further witness to the ambiguous interplay between sexuality and political authority. Dominic Janes notes how a variety of Bloomsbury intellectuals, and in particular Lytton Strachey and John Maynard Keynes, were able to distance themselves from contemporary masculine norms to critique performances of masculinity by prominent public figures, notably the participants in the peace conferences in the aftermath of the First World War.

By the early twentieth century, the criteria by which masculinity was defined were no longer something that could be taken as given. This led to phenomena of critique, but also of reactionary reassertion could itself be innovative. Christopher Dillon describes how, during the Nazi takeover of 1930 to 1934, there was a difficult and hesitating interaction between the controlled, authoritarian masculinities of traditional conservatives and the violent, beer hall masculinity of emergent National Socialism. He reveals that although propaganda portrayed this interaction as a simple victory of Nazi virility over Weimer emasculation, the development of Nazi masculinity during this period was actually more hesitant and internally conflictual than might at first appear. Nazi self-presentation had to struggle both with the homosexuality of several of its prominent members within an overtly homophobe movement, and with the non-correspondence between Hitler's dandyish lifestyle and the manly austerity of his public image.

The two final contributions to the volume consider the interplay between norms of masculinity and changing forms of political culture up to the present day, considering how masculinities affected the ability to be an effective political agent. Ben Griffin examines the extent to which the 'gentlemanly' masculinity which had enabled professional and middle class men to be absorbed into the parliamentary political class without excessive friction in the late nineteenth and early twentieth centuries stood in the way of the later integration of women and working class men. He considers how far parliamentary culture succeeded in adapting to these changes, focusing on the problems which MPs, and especially male Labour MPs, experienced in navigating between the masculine ideals of their supporters and those of the Houses of Parliament. Finally, Stephen Gundle considers the continuing competition of different masculinities, still attendant on the overwhelmingly male-dominated nature of politics, in Italy from the Second World War to the 1990s. Gundle places the particular masculinity of Silvio Berlusconi in historical perspective, examining how the post-war model of a competent, business-like political masculinity was nonetheless still haunted by the ghost of Mussolini's hyper-masculinity. The collapse and transformation of the political culture which supported these conflicted masculinities casts new light both on Berlusconi's own contradictory masculinity and the significance of his rise, and on the importance of gender and masculinity for the study of modern Italian politics.

In the case studies brought together in this volume, stretching over two millennia, different political cultures have interacted in different ways with a wide variety of norms associated in whole or in part with adult maleness. Sometimes these norms have been deployed for political ends, sometimes they have structured politics without the participants necessarily being aware that this was happening. In certain circumstances masculine norms have been critiqued or left aside for political 
purposes, at other moments they have been re-asserted for political ends. What emerges above all is that masculinity has constantly played an important role in the configuration of political life, from the Roman Empire to the present day. This volume shows how historians who concentrate on the intersection between masculinity and political culture can make a vital contribution to our understanding of both the history of gender and the history of politics.

\footnotetext{
${ }^{1}$ Max Weber, 'Politics as a Vocation' [1919] in The Vocation Lectures, trans. R. Livingstone (Indianopolis and Cambridge: Hackett, 2004), p. 32.

${ }^{2}$ For the introduction of women into electoral politics and the backlash against it, see Christopher Dillon's article, below.
}

${ }^{3}$ J.A. McNamara and S. Wemple, 'The Power of Women through the Family in Medieval Europe: 500-1100', Feminist Studies, 1 (1973), 126-141; J.A. McNamara, 'Women and power through the family revisited' in Gendering the Master Narrative: Women and Power in the Middle Ages, ed. M.C. Erler and M. Kowaleksi (Ithaca: Cornell Univ. Press, 2003$), 17-$ 30.

${ }^{4}$ In an enormous bibliography, see e.g. R. Le Jan, Femmes, pouvoir et société dans le haut Moyen Âge (Paris: Picard, 2001); P. Stafford, Queens, Concubines and Dowagers: The King's Wife in the Early Middle Ages (London: Leicester Univ. Press, 1998); T. Earenfight, Queenship in medieval Europe (Basingstoke: Palgrave, 2013); M. Bubenicek, Quand les femmes gouvernent: droit et politique au XIV siècle (Paris: Ecole des Chartes, 2002); J.C. Ward, English Noblewomen in the Later Middle Ages (London: Longman, 1992); C. Levin, The Heart and Stomach of a King": Elizabeth I and the Poltics of Sex and Power (Philadelphia: Univ. of Pennsylvania Press, 1995); F. Cosandey, La reine de France: Symbole et pouvoir (Paris: Gallimard, 2000); D. Conroy, Ruling Women, vol. I. Government, Virtue and the Female Prince in seventeenth-century France (Basingstoke: Palgrave Macmillan, 2016).

${ }^{5}$ Cosandey, La reine de France, esp. pp. 295-332.

${ }^{6}$ For this coinage see Weber, Politics as a Vocation, pp. 36-38.

7 Weber's powerful theorisation of an ideal type of 'politics' defined by its dependence on an equally idealised 'state' was very much a product of its time. His historical account exists to support his sociological analysis of what interests him in the world of 1919, leading him to overstate the importance of certain social processes and to prematurely exclude others. That said, it is true that he does identify a number of developments which historians still consider to be important in the changing nature of politics in medieval and modern Europe. For a recent consideration of similar processes in the light of modern research, see J.L. Watts, The Making of Polities (Cambridge: Cambridge University Press, 2009).

${ }^{8}$ See De Bono Communi: The Discourse and Practice of the Common Good in the European City $\left(13^{\text {th }}-16^{\text {th }}\right.$ centuries), ed. E. LecuppreDesjardin and A.-L. Van Bruaene (Turnhout: Brepols, 2010); Pouvoir d'un seul et bien commun (VIe-XVTe siècles), ed. F. Collard special ed. Revue francaise d'histoire des idées politiques, 32 (2010).

${ }_{9}$ Although in the context of the French revolution, see D. Outram, The Body and the French Revolution: Sex, class and political culture (New Haven: Yale Univ. Press, 1989).

${ }^{10}$ See e.g. C. Pateman, The Disorder of Women: Democracy, feminism and political theory (Stanford: Stanford Univ. Press, 1989); M.-J. Bertini, Femmes: Le pouvoir impossible (Paris: Pauvert, 2002).

11 See for example A. Verjus, Le bon mari: Une histoire politique des hommes et des femmes à l'époque révolutionnaire (Paris: Fayard, 2010); B. Griffin, The Politics of Gender in Victorian Britain: Masculinity, Political Culture and the Struggle for Women's Rights (Cambridge: Cambridge Univ. Press, 2012); M. McCormack, The Independent Man: Citizenship and Gender Politics in Georgian England (Manchester: Manchester Univ. Press, 2005); and the contributions to Public Men: Masculinity and Politics in Modern Britain, ed. M. McCormack (Basingstoke: Palgrave, 2007); Masculinities in politics and war: Gendering modern bistory, ed. S. Dudink, K. Hagemann and J. Tosh (Manchester: Manchester Univ. Press, 2004).

${ }^{12}$ For crucial developments in the emergence of the 'state' between the thirteenth and the fifteenth century, see in particular the work sponsored by the European Science Foundation to examine the 'Origins of the Modern State', notably: L'Etat moderne, genèse: bilans et perspectives, ed. J.-P. Genet (Paris: CNRS, 1990); Etat et Eglise dans la genèse de l'Etat moderne, ed. J.-P. Genet and B. Vincent (Madrid: Casa de Velázquez, 1986); Genèse de l'Etat moderne: prélèvement et redistribution, ed. J.P. Genet and M. Le Mené (Paris: CNRS, 1987); La ville, la bourgeoisie et la genèse de l'Etat moderne (XIIeXVIIIe siècles), ed. N. Bulst and J.-P. Genet (Paris, CNRS, 1988); L'Etat moderne, le droit, l'espace et les formes de l'Etat, ed. N. Coulet and J.-P. Genet (Paris: CNRS, 1990); Economic systems and state finance, ed. R. Bonney, W. Blockmans and J.P. Genet (Oxford, Clarendon, 1995); L'Etat moderne et les élites, XIIIe-XVIIIe siècles, ed. J.-P. Genet and G. Lottes (Paris: Publications de la Sorbonne, 1996); Cities and the rise of states in Europe, A.D. 1000 to 1800, ed. C. Tilly and W.P. Blockmans (Boulder: Westview Press, 1994); Resistance, representation and community, ed. P. Blickle (Oxford: Clarendon Press, 1997). For an essential critical synthesis, see Watts, The Making of Polities. For the intense 'state formation' of

Institutional deposit of pre-copy-edited version. Please consult and cite: Christopher Fletcher, 'Introduction: Masculinity and Politik' in Christopher Fletcher, Sean Brady, Rachel E. Moss and Lucy Riall, eds., The Palgrave Handbook of Masculinity and Political Culture in Europe (London: Palgrave Macmillan, 2018), pp. 1-16. DOI: 10.1057/978-1-13758538-7 
early modern England, see M. Braddick, State formation in early modern England, c. 1550-1700 (Cambridge: Cambridge Univ. Press, 2000).

${ }^{13}$ C. Schmidt, The Concept of the Political, trans. G. Schwab (Chicago: Univ. of Chicago Press, 1996 [1932]), esp. p. 20.

14 On the composition of the 'field' of politics in modern France, see P. Bourdieu, 'La logique des champs' in his Réponses (Paris: Seuil, 1992), pp. 71-90.

15 P. Rosanvallon, La contre-démocratie: La politique à l'âge de la défiance (Paris: Seuil, 2006); Idem, Le bon gouvernement (Paris: Seuil, 2015).

16 The citation is Weber, 'Politics as a vocation', p. 39, but the theme is explored most fully by Rosanvallon, La contredémocratie, esp. pp. 24-38.

${ }^{17}$ L. Davidoff and C. Hall, Family Fortunes: Men and Women of the English Middle Class, 1780-1850 (London: Hutchinson, 1987); J. Tosh, A Man's Place: Masculinity and the Middle-Class Home in Victorian England (New Haven: Yale Univ. Press, 1999). For a valid critique of the chronologies imposed on the development of the division between public and private, which does not however undermine its significance as a political category, see A. Vickery, 'Golden age to separate spheres? A review of the categories and the chronology of English women's history', Historical Journal, 36 (1993), 383414.

${ }^{18}$ For recent explorations of the relationship between masculine domestic and political virtue in early modern England, see K. Harvey, The Little Republic (Oxford: Oxford Univ. Press, 2012); Verjus, Le bon mari.

${ }^{19}$ For a short survey of these developments, see J.L. Watts, 'Introduction' in Political Society in Later Medieval England, ed. B. Thompson and J. Watts (Woodbridge: Boydell, 2015), pp. 1-7.

${ }^{20}$ C. Carpenter, 'Introduction: Political Culture, Politics and Cultural History' in The Fifteenth Century IV: Political Culture in Late Medieval Britain, ed. L. Clark and C. Carpenter (Woodbridge: Boydell, 2004), pp. 1-19.

${ }^{21}$ See below, Schlagdenhauffen, Oliva Herrer.

${ }^{22}$ For an exploration of its multiple historical uses, see What is Masculinity? Historical Dynamcs from Antiquity to the Contemporary World, ed. J.H. Arnold and S. Brady (Basingstoke: Palgrave, 2011).

23 See esp. D. Gilmore, Manhood in the making: Cultural concepts of masculinity (New Haven: Yale Univ. Press, 1990) and the critique of R.W. Connell, Masculinities (Berkeley and Los Angeles: Univ. of California Press, 2nd edn. 2005), pp. 323.

${ }^{24}$ Connell, Masculinites., pp. 55-6, 76-81, 89-181. Although the growth of transgender studies is currently reshaping assumptions of commonalties of bodily experience also. See M.J. Boucher, 'Do you have what it takes to be a real man?' in Performing American Masculinities: The Twenty-First Century Man in Popular Culture, ed. E. Watson and M.E. Shaw (Bloomington: Indiana Univ. Press, 2011), pp. 192-232.

25 See below esp. Dumas, Leleu, Oliva Herrer, Doran.

${ }^{26}$ C. Fletcher, 'Sire, uns hom sui: Transgression et inversion par rapport à quelle(s) norme(s) dans l'histoire des masculinités médiévales?’, Micrologus' Library, 25 (2017), forthcoming.

${ }^{27}$ For 'virtus', see M. McDonnell, Roman Manliness: Virtus and the Roman Republic (Cambridge: Cambridge Univ. Press, 2006); S. Schwandt, Virtus: Zur Semantik eines politischen Konzepts im Mittelalter (Frankfurt: Campus, 2014).

${ }_{28}$ M. Kuefler, The Manly Eunuch: Masculinity, Gender Ambiguity and Christian Ideology in Late Antiquity (Chicago: Univ. of Chicago Press, 2001); K.A. Smith, War and the making of medieval monastic culture (Woodbridge: Boydell, 2011).

29 A. Shepard, 'Manhood, credit and patriarchy in early modern England, c. 1560-1640', Past and Present, 167 (2000), 75-106.

${ }^{30}$ R. Moss, 'An Orchard, a Love Letter and Three Bastards: The Formation of Adult Male Identity in a FifteenthCentury Family' in What is Masculinity?, ed. Brady and Arnold, pp. 226-44; C. Fletcher, Richard II: Manhood, youth and politics (Oxford: Oxford Univ. Press, 2008), pp. 60-73.

31 See below, Vohra.

32 On which, see below Gundle.

33 See below, Dillon.

${ }^{34}$ See further below, Griffin. Cf. the ambiguous role of tears and emotional expression in the seventeenth century, discussed by B. Capp, "Jesus Wept" but did the Englishman? Masculinity and Emotion in Early Modern England', Past and Present, 224 (2014), 75-108.

35 A. Shepard, Meanings of Manhood in Early Modern England (Oxford: Oxford Univ. Press, 2003), pp. 21-92; K. Harvey, The Little Republic: Masculinity and Domestic Authority in Eighteenth-Century Britain (Oxford: Oxford Univ. Press, 2012), pp. 24-63.

${ }^{36}$ Fletcher, Richard II: Manhood, youth and politics, pp. 60-73; Oliva Herrer and Doran below.

${ }^{37}$ For 'habitus' see P. Bourdieu, Esquisse d'une théorie de la pratique (Paris: Seuil, 2000 [1972]), trans. as Idem, Outline of a theory of practice, trans. R. Nice (Cambridge: Cambridge Univ. Press, 1977)

38 Competition between masculinities is essential to Connell's analysis also. See Connell, Masculinities, pp. 71-81.

${ }^{39}$ Histoire de la virilité, ed. A. Corbin, J.-J. Courtine and G. Vigarello, 3 vols. (Paris: Seuil, 2011).

${ }^{40}$ For a critique, see H. French and M. Rothery, Man's Estate: Landed Gentry Masculinities, 1660-1900 (Oxford: Oxford Univ. Press, 2012); and McCormack, below.

Institutional deposit of pre-copy-edited version. Please consult and cite: Christopher Fletcher, 'Introduction:

Masculinity and Politike' in Christopher Fletcher, Sean Brady, Rachel E. Moss and Lucy Riall, eds., The Palgrave Handbook of Masculinity and Political Culture in Europe (London: Palgrave Macmillan, 2018), pp. 1-16. DOI: 10.1057/978-1-13758538-7 